\title{
ANALISIS DAYA DUKUNG FONDASI ENLARGED BASE BERDASARKAN DATA N-SPT DENGAN PROGRAM MICROSOFT EXCEL
}

\author{
Renaldi Caecario ${ }^{1}$ dan Andryan Suhendra ${ }^{2}$ \\ ${ }^{1}$ Program Studi Sarjana Teknik Sipil, Universitas Tarumanagara, Jl. Letjen S. Parman No.1 Jakarta \\ Email: renaldicaecario@gmail.com \\ ${ }^{2}$ Program Studi Sarjana Teknik Sipil, Universitas Tarumanagara, Jl. Letjen S. Parman No.1 Jakarta \\ Email: andryansuhendra@yahoo.com
}

\begin{abstract}
ABSTRAK
Secara umum fungsi fondasi adalah untuk meneruskan gaya yang diterimanya ke tanah dasar fondasi. Fondasi dalam digunakan apabila lapisan tanah keras terletak sangat dalam, untuk itu tipe fondasi yang cocok adalah tiang tahanan ujung sebagai penerus beban melalui ujungnya ke lapisan keras yang memiliki kuat dukung tinggi. Pada penulisan ini yang akan dibahas adalah tiang bor yang ujungnya diperbesar berbentuk trapesium. Berbeda dengan tiang bor lurus, tiang bor yang ujungnya diperbesar berbentuk trapesium akan memiliki daya dukung ujung lebih besar, karena pada prinsipnya bagian ujung fondasi dalam yang memiliki bentuk trapesium sama seperti fondasi dangkal. Jadi fondasi tiang bor yang ujungnya diperbesar berbentuk trapesium adalah fondasi dangkal yang diteruskan ke dalam tanah sampai mencapai tanah keras. Pada penulisan ini akan dilakukan analisis daya dukung vertikal dan penurunan seketika mengenai fondasi yang ujungnya diperbesar atau fondasi enlarged base. Karena perhitungan fondasi enlarged base lebih rumit dan sulit dibandingkan dengan menghitung fondasi tiang bor lurus, untuk mempermudah perhitungan akan dibuat dalam bentuk spreadsheet dengan program Microsoft Excel, yang akan menghasilkan perhitungan daya dukung selimut, daya dukung ujung, daya dukung ultimit, daya dukung ijin, dan penurunan seketika fondasi enlarged base. Dan untuk mengetahui apakah hasil perhitungan spreadsheet tersebut dapat di andalkan, akan dilakukan perbandingan dengan software komputer lain.
\end{abstract}

Kata kunci: fondasi tiang bor, daya dukung dan penurunan seketika fondasi enlarged base.

\section{PENDAHULUAN}

Menurut Coduto, Kitch dan Yeung (2016: 4), tidak mungkin struktur atas bangunan menjadi kuat dan handal, apabila tidak di bangun di atas struktur bawah (fondasi) yang baik. Jika fondasi gagal, maka struktur di atasnya akan ikut gagal. Dan terkadang fondasi dalam memerlukan biaya yang sangat mahal, sehingga bangunan gedung menjadi tidak efisien. Oleh karena itu, diperlukan perencanaan dan pemilihan yang tepat untuk jenis fondasi yang akan digunakan, di sesuaikan dengan jenis tanah dan beban dari struktur di atasnya. Berbagai macam jenis fondasi yang berkembang saat ini, memiliki tujuan yaitu untuk mendapatkan jenis fondasi yang paling efisien, karena tidak ada fondasi yang baik/unggul di semua aspek. Gedung bertingkat di perkotaan, umumnya menggunakan tiang bor (bore pile) karena alasan lahan yang berdekatan dengan gedung yang sudah ada, karena tiang bor saat pembuatan tidak mengeluarkan suara yang besar dan tidak menimbulkan getaran yang berlebihan. Salah satu jenis fondasi tiang bor yang mengandalkan daya dukung ujungnya adalah fondasi ujung diperbesar atau fondasi enlarged base. Akan tetapi pembuatan fondasi enlarged base di lapangan lebih rumit dan sulit dibandingkan dengan fondasi bor lurus biasa. Selain pembuatannya di lapangan yang sulit, fondasi enlarged base juga lebih sulit untuk dihitung/didesain. Dengan teknologi yang semakin berkembang, pelaksanaan konstruksi untuk fondasi enlarged base bukan lagi hal yang mustahil. Seperti pada contoh Gambar 1, merupakan ilustrasi proses pengeboran dan pengecoran fondasi enlarged base yang dilakukan oleh suatu perusahaan konstruksi di Australia. 


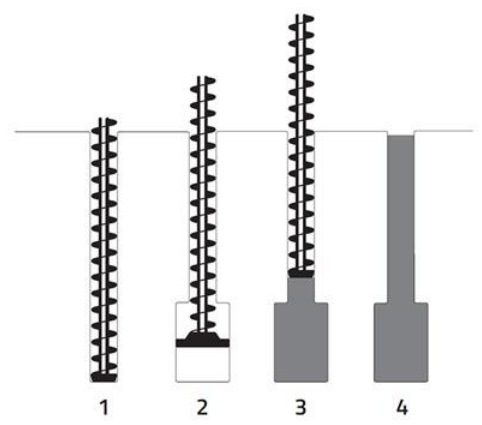

Gambar 1. Ilustrasi pengeboran dan pengecoran fondasi enlarged base

Akan tetapi untuk mendasain fondasi enlarged base memerlukan waktu yang lebih lama karena perhitungannya yang lebih sulit dan rumit dibandingkan dengan fondasi bor lurus biasa. Oleh sebab itu, untuk mempercepat dan mempermudah perhitungan daya dukung dan penurunan fondasi enlarged base, akan dibuat suatu lembar kerja atau spreadsheet dengan bantuan program Microsoft Excel.

\section{Batasan masalah}

- Fondasi enlarged base dianggap hanya menahan gaya aksial saja, gaya lateral dan gaya gempa diabaikan. Serta hanya mencakup tiang tunggal free head dan end bearing.

- Pembahasan tidak mencakup pembesian fondasi, fondasi juga dianggap tidak memiliki kemiringan, tertimbun seluruhnya dibawah permukaan tanah dan berada pada permukaan tanah yang rata.

- Spreadsheet yang akan dibuat tidak memperhatikan kekuatan dari bahan, sehingga saat mendesain perlu mengecek kekuatan bahan tiang enlarged base. Serta segala kemungkinan kegagalan selama proses konstruksi diabaikan.

- Data tanah yang tersedia hanya sampai kedalaman 30 meter dan bentuk pembesaran fondasi dianggap miring dengan kemiringan $1 \mathrm{~V}: 1 \mathrm{H}$.

\section{Maksud dan tujuan}

Maksud dan tujuan dibuatnya penulisan ini adalah untuk mempermudah perhitungan daya dukung fondasi enlarged base baik di tanah non-kohesif (pasir) dan kohesif (lempung/lanau) dengan spreadsheet dan hasilnya dibandingkan dengan software komputer. Dan juga untuk mempermudah perhitungan penurunan seketika dari fondasi enlarged base dengan spreadsheet yang hasilnya juga akan dibandingkan dengan software komputer.

\section{TINJAUAN PUSTAKA}

Menurut Moch. Sholeh (2008), berbagai tipe fondasi tiang sangat tergantung pada beban yang bekerja pada fondasi tersebut, kondisi tanah sekitar, bahan fondasi yang ada dan cara-cara pelaksanaan yang tersedia. Beberapa perbedaan tipe fondasi tiang dilihat dari cara tiang meneruskan bebannya adalah yang pertama tiang tahanan ujung (end bearing pile) yaitu tiang yang meneruskan beban melaluo ujungnya ke lapisan tanah keras/baik dengan kuat dukung tinggi, kedua tiang gesekan (friction pile) yaitu tiang yang meneruskan beban melalui gesekan antara permukaan tiang dengan tanah sekelilingnya, ketiga tiang lekatan (adhesive pile) yaitu tiang yang menerukan beban melalui lekatan atara permukaan tiang dengan tanah sekelilingnya. Setelah ditemukan fondasi tiang bor, seorang belgian engineer yaitu Edgard Fankiegnoul pada tahun 1909 berhasil menemukan metode baru yaitu expanded pile yang telah diakui oleh dunia. Teknologi yang terus berkembang membuat saat ini ditemuka metode yang memiliki kemiripan dengan frankie pile yaitu fondasi ujung diperbesar atau fondasi enlarged base .

\section{METODOLOGI PENELITIAN}

Dalam penulisan ini dilakukan beberapa tahapan yang dapat diuraikan sebagai berikut:

Tahapan pertama adalah melakukan pengumpulan data berupa data tanah (hasil tes boring log dan buku referensi maupun jurnal yang terkait.

Tahapan kedua adalah membuat spreadsheet dalam program Microsoft Excel berupa korelasi tanah dan membuat analisis daya dukung dan penurunan fondasi enlarged base.

Tahapan ketiga adalah membuat contoh hasil daya dukung dan penurunan fondasi enlarged base, baik dari spreadsheet ataupun software komputer lain. 
Tahapan keempat adalah melakukan analisis perbandingan antara hasil perhitungan daya dukung selimut, ujung, ultimit dan penurunan dari contoh fondasi enlarged antara spreadsheet dengan software komputer lain.

Tahapan kelima adalah menarik kesimpulan berdasarkan hasil perbandingan pada tahap keempat, untuk mengetahui apakah perhitungan dari spreadsheet dapat diandalkan/tidak.

\section{ANALISIS DAN PEMBAHASAN}

Data tanah yang digunakan didapat dari hasil test tanah yang dilakukan oleh suatu perusahaan konstruksi, terdiri dari 3 borlog dari proyek yang berlokasi di Tangerang Selatan, 1 borlog dari proyek yang berlokasi di Jakarta Pusat dan 1 borlog dari proyek yang berlokasi di Sumatra Utara. Hasil test tanah sudah disederhanakan seperti pada tabel 1.

Tabel 1. Lapisan Tanah

\begin{tabular}{|c|c|c|c|c|c|c|c|c|c|c|}
\hline \multirow[t]{2}{*}{ LOKASI: } & \multicolumn{6}{|c|}{$\begin{array}{c}\text { TANGERANG SELATAN } \\
\end{array}$} & \multicolumn{2}{|c|}{ JAKARTA PUSAT } & \multicolumn{2}{|c|}{ SUMATRA UTARA } \\
\hline & BL 1 & MAT $=-1.40$ & BL 2 & MAT $=-1.30$ & BL 3 & MAT $=-1.20$ & BL 1 & MAT $=-2.5$ & BL 1 & MAT $=0$ \\
\hline Depth $(\mathrm{m})$ & $\mathrm{N}$ & Soil & $\mathrm{N}$ & Soil & $\mathrm{N}$ & Soil & $\mathrm{N}$ & Soil & $\mathrm{N}$ & Soil \\
\hline 0 & 0.0 & \multirow{6}{*}{ Sandy Silt } & 0.0 & \multirow{7}{*}{ Clay } & 0.0 & \multirow{9}{*}{ Clay } & 7.0 & \multirow{2}{*}{ Fill Material } & 0 & - \\
\hline 1 & 9.0 & & 4.5 & & 3.0 & & 7.0 & & 0 & - \\
\hline 2 & 18.0 & & 9.0 & & 6.0 & & 7.0 & \multirow{21}{*}{ Clayey Silt } & 11 & \multirow{2}{*}{ Silt } \\
\hline 3 & 34.0 & & 22.0 & & 6.5 & & 7.0 & & 11 & \\
\hline 4 & 50.0 & & 35.0 & & 7.0 & & 7.0 & & 34 & \multirow{3}{*}{ Sand } \\
\hline 5 & 50.0 & & 42.5 & & 8.0 & & 3.0 & & 34 & \\
\hline 6 & 50.0 & \multirow{4}{*}{ Cemented Silt } & 50.0 & & 9.0 & & 3.0 & & 34 & \\
\hline 7 & 50.0 & & 50.0 & \multirow{2}{*}{$\begin{array}{l}\text { Sand with } \\
\text { Coral }\end{array}$} & 29.5 & & 3.0 & & 8 & \multirow{15}{*}{ Sandy Silt } \\
\hline 8 & 50.0 & & 50.0 & & 50.0 & & 3.0 & & 8 & \\
\hline 9 & 35.0 & & 50.0 & \multirow{2}{*}{ Coarse Sand } & 50.0 & \multirow{2}{*}{$\begin{array}{c}\text { Cemented } \\
\text { Sand }\end{array}$} & 3.0 & & 8 & \\
\hline 10 & 20.0 & \multirow{4}{*}{ Silt } & 50.0 & & 50.0 & & 3.0 & & 8 & \\
\hline 11 & 24.5 & & 50.0 & \multirow{2}{*}{ Fine Sand } & 50.0 & \multirow{2}{*}{ Coarse Sand } & 3.0 & & 8 & \\
\hline 12 & 29.0 & & 50.0 & & 50.0 & & 3.0 & & 8 & \\
\hline 13 & 24.0 & & 50.0 & \multirow{2}{*}{$\begin{array}{l}\text { Coarse Sand } \\
\text { with Coral }\end{array}$} & 50.0 & \multirow{2}{*}{ Fine Sand } & 7.0 & & 8 & \\
\hline 14 & 19.0 & \multirow{2}{*}{ Organic Silt } & 50.0 & & 50.0 & & 7.0 & & 8 & \\
\hline 15 & 34.5 & & 50.0 & \multirow{4}{*}{ Coarse Sand } & 50.0 & \multirow{2}{*}{ Sandy Silt } & 7.0 & & 8 & \\
\hline 16 & 50.0 & \multirow{2}{*}{ Silt } & 50.0 & & 50.0 & & 7.0 & & 8 & \\
\hline 17 & 50.0 & & 50.0 & & 50.0 & \multirow{4}{*}{ Coarse Sand } & 5.0 & & 8 & \\
\hline 18 & 50.0 & \multirow{2}{*}{ Fine Sand } & 50.0 & & 50.0 & & 5.0 & & 8 & \\
\hline 19 & 50.0 & & 50.0 & & 50.0 & & 5.0 & & 8 & \\
\hline 20 & 50.0 & & 50.0 & Fine Sand & 50.0 & & 5.0 & & 8 & \\
\hline 21 & 47.5 & Cloyey Sond & 50.0 & Fine Sand & 50.0 & Sand dy Silt & 5.0 & & 50 & \\
\hline 22 & 45.0 & Clayey Sand & 50.0 & & 50.0 & Sandy silt & 5.0 & & 50 & \\
\hline 23 & 47.5 & & 42.0 & Coorese S & 47.5 & & 5.0 & & 50 & Silty Sond \\
\hline 24 & 50.0 & Sandy Silt & 34.0 & Coarse Sand & 45.0 & Fine Sand & 19.0 & Clay & 50 & Silty Sand \\
\hline 25 & 50.0 & Sandy silt & 42.0 & Siltu Clov & 43.5 & & 19.0 & & 50 & \\
\hline 26 & 50.0 & Coarse Sand & 50.0 & sitty clay & 42.0 & & 19.0 & & & \\
\hline 27 & 50.0 & with Gravel & 50.0 & & 44.5 & Silt & 19.0 & Silty & & \\
\hline 28 & 50.0 & & 50.0 & Fine Sand & 47.0 & Silt & 19.0 & Silty Clay & & \\
\hline 29 & 50.0 & Clayey Silt & 42.5 & Silty Clay with & 41.0 & & 19.0 & & & \\
\hline 30 & 50.0 & & 35.0 & Coral & 35.0 & & 19.0 & & & \\
\hline
\end{tabular}

Analisis kapasitas tiang yang dilakukan menggunakan metode sebagai berikut; daya dukung ujung fondasi enlarged base menggunakan metode dari buku dari Braja M.Das (2011), daya dukung selimut fondasi enlarged base menggunakan metode Bowles (1992) dan analisis penurunan tiang menggunakan metode semi empiris.

\section{Daya dukung ijin fondasi enlarged base}

Estimasi kapasitas daya dukung ultimit dan ijin dari fondasi enlarged base, yaitu:

$$
Q_{\text {all }}=\frac{Q_{p}}{S F}+\frac{Q_{S}}{S F}
$$


Dengan $\mathrm{Q}_{\mathrm{all}}=$ daya dukung ijin fondasi (allowable), $\mathrm{Q}_{\mathrm{p}}=$ daya dukung ujung fondasi, $\mathrm{Q}_{\mathrm{s}}=$ daya dukung selimut fondasi, $\mathrm{SF}$ = faktor keamanan (diambil 3 untuk daya dukung ujung dan daya dukung selimut fondasi).

\section{Daya dukung ujung fondasi enlarged base}

Daya dukung ujung fondasi enlarged base pada tanah non-kohesif dapat dihitung dengan persamaan:

$$
Q_{p}=A_{p} \times\left[q^{\prime} \times\left(N_{q}-1\right) \times F_{q s} \times F_{q d} \times F_{q c}\right]
$$

Dengan $\mathrm{A}_{\mathrm{p}}$ = luas penampang dasar fondasi, $\mathrm{q}^{\prime}=$ tekanan vertikal efektif di dasar fondasi, $\mathrm{N}_{\mathrm{q}}=$ faktor bearıng capacity, $\mathrm{F}_{\mathrm{qs}}=$ faktor bentuk fondasi, $\mathrm{F}_{\mathrm{qd}}=$ faktor kedalaman fondasi, $\mathrm{F}_{\mathrm{qc}}=$ faktor kompresibilitas.

Dan besar nilai daya dukung ujung fondasi enlarged base pada tanah non-kohesif memiliki batasan yang didapat dari metode Mayerhof, sehingga nilai $Q_{p}$ pada tanah non-kohesif tidak boleh lebih besar nilainya dari yaitu persamaan:

$$
Q_{p}=A_{p} \times 0,5 \times P_{a} \times N_{q} \times \tan \phi^{\prime}
$$

Dengan $\mathrm{P}_{\mathrm{a}}=$ tekanan atmosfir $\left(100 \mathrm{kN} / \mathrm{m}^{2}\right), \phi^{\prime}=$ sudut geser dalam efektif.

Daya dukung ujung fondasi enlarged base pada tanah koheisf dapat dihitung dengan persamaan:

$$
Q_{p}=A_{p} \times c_{u} \times N_{q} \times F_{c s} \times F_{c d} \times F_{c c}
$$

Dengan $\mathrm{c}_{\mathrm{u}}=$ kohesi tak teralir, $\mathrm{N}_{\mathrm{q}}=$ faktor bearing capacity, $\mathrm{F}_{\mathrm{cs}}=$ faktor bentuk fondasi, $\mathrm{F}_{\mathrm{cd}}=$ faktor kedalaman fondasi, $\mathrm{F}_{\mathrm{cc}}=$ faktor kompresibilitas.

\section{Daya dukung selimut fondasi enlarged base}

Daya dukung selimut fondasi enlarged base dihitung dengan menggunakan persamaan:

$$
Q_{s}=p \sum f_{i} \times L_{i}
$$

Dengan $\mathrm{p}=$ keliling penampang tiang, $\mathrm{f}_{\mathrm{i}}=$ tahanan selimut tiang bor, $\mathrm{L}_{\mathrm{i}}=$ tebal lapisan tahanan selimut.

\section{Penurunan seketika fondasi enlarged base}

Penurunan fondasi enlarged base dihitung dengan menggunakan persamaan berikut:

$$
S_{e}=S_{s}+S_{p}+S_{p s}
$$

Dengan $S_{e}=$ penurunan elastis total fondasi tiang tunggal, $S_{\mathrm{s}}=$ penurunan akibat deformasi aksial tiang tunggal, $\mathrm{S}_{\mathrm{p}}=$ penurunan dari ujung tiang, $\mathrm{S}_{\mathrm{ps}}=$ penurunan tiang akibat beban yang dialihkan sepanjang tiang.

Penurunan akibat deformasi aksial tiang tunggal dapat dihitung dengan persamaan:

$$
\mathrm{S}_{\mathrm{s}}=\frac{\left(\mathrm{Q}_{\mathrm{p}}+\alpha \cdot \mathrm{Q}_{\mathrm{s}}\right) \cdot \mathrm{L}}{\mathrm{A}_{\mathrm{p}} \cdot \mathrm{E}_{\mathrm{p}}}
$$

Dengan $\alpha=$ koefisien yang bergantung pada distribusi gesekan selimut sepanjang fondasi tiang, $\mathrm{E}_{\mathrm{p}}=$ modulus elastisitas tiang.

Penurunan dari ujung tiang dapat dihitung dengan persamaan:

$$
\mathrm{S}_{\mathrm{p}}=\frac{\mathrm{C}_{\mathrm{p}} \cdot \mathrm{Q}_{\mathrm{p}}}{\mathrm{D} \cdot \mathrm{q}_{\mathrm{p}}}
$$

Dengan $\mathrm{C}_{\mathrm{p}}=$ koefisien empiris, $\mathrm{q}_{\mathrm{p}}=$ tahanan ujung tiang.

Penurunan akibat deformasi aksial tiang tunggal dapat dihitung dengan persamaan:

$$
\mathrm{S}_{\mathrm{ps}}=\left(\frac{\mathrm{Q}_{\mathrm{ws}}}{\mathrm{p} \cdot \mathrm{L}}\right) \cdot \frac{\mathrm{D}}{\mathrm{E}_{\mathrm{s}}} \cdot\left(1-\mathrm{v}_{\mathrm{s}}^{2}\right) \cdot \mathrm{I}_{\mathrm{ws}}
$$

Dengan $\mathrm{p}=$ keliling tiang, $\mathrm{v}_{\mathrm{s}}=$ angka Poisson tanah, $\mathrm{I}_{\mathrm{ws}}=$ faktor pengaruh, $\frac{Q_{w s}}{p \cdot L}=$ gesekan rata-rata sepanjang tiang. 


\section{HASIL ANALISIS}

Pada hasil analisis, akan dilakukan perbandingan antara perhitungan daya dukung dan penurunan yang dihasilkan oleh spreadsheet yang telah dibuat dan dengan software komputer lain. Perbandingan hasil perhitungan fondasi enlarged base dilakukan untuk mengetahui apakah spreadsheet yang telah dibuat dapat diandalakn atau tidak untuk menghitung daya dukung selimut $\left(\mathrm{Q}_{\mathrm{s}}\right)$, daya dukung ujung $\left(\mathrm{Q}_{\mathrm{p}}\right)$, daya dukung ultimit $\left(\mathrm{Q}_{\mathrm{ult}}\right)$ dan penurunan seketika $\left(\mathrm{S}_{\text {total }}\right)$ dari fondasi enlarged base. Oleh sebab itu, dibuat 7 jenis fondasi enlarged base dari 5 borlog yang berbeda sebagai contoh perbandingan hasil perhitungan yang dilakukan oleh spreadsheet dengan software komputer lain. Pada tabel 2 dapat dilihat seperti apa spesifikasi fondasi enlarged base yang akan dibuat (pada ke-7 contoh fondasi enlarged base diabaikan kekuatan bahannya). Pada tabel 3 dapat dilihat hasil perhitungan fondasi enlarged base tabel 2, dari spreadsheet dan software komputer. Sehingga selisih perhitungan daya dukung selimut, ujung, ultimit dan penurunan seketika antara spreadsheet dan software komputer dapat dilihat pada tabel 4.

Tabel 2. Spesifikasi fondasi sebagai contoh perhitungan

\begin{tabular}{|c|c|c|c|c|c|c|}
\hline \multirow{2}{*}{$\begin{array}{l}\text { Tiang } \\
\text { No. }\end{array}$} & $\begin{array}{c}\text { Panjang } \\
\text { Tiang Total }\end{array}$ & $\begin{array}{c}\text { Panjang Tiang Sebelum } \\
\text { Pembesaran }\end{array}$ & $\begin{array}{l}\text { Panjang Tiang } \\
\text { Sesudah Pembesaran }\end{array}$ & $\begin{array}{l}\text { Diameter Tiang } \\
\text { Sebelum Pembesaran }\end{array}$ & $\begin{array}{c}\text { Diameter Tiang } \\
\text { Sesudah Pembesaran }\end{array}$ & \multirow[t]{2}{*}{ Data Tanah } \\
\hline & $(\mathrm{H})$ & $\left(\mathrm{H}_{\mathrm{s}}\right)$ & $(\mathrm{Hb})$ & $\left(\mathrm{D}_{\mathrm{s}}\right)$ & $\left(\mathrm{D}_{\mathrm{b}}\right)$ & \\
\hline 1 & $6 \mathrm{~m}$ & $5 \mathrm{~m}$ & $1 \mathrm{~m}$ & $0,3 \mathrm{~m}$ & $0,6 \mathrm{~m}$ & Tangerang Selatan (BL2) \\
\hline 2 & $10 \mathrm{~m}$ & $9 \mathrm{~m}$ & $1 \mathrm{~m}$ & $0,3 \mathrm{~m}$ & $0,6 \mathrm{~m}$ & Tangerang Selatan (BL3) \\
\hline 3 & $12 \mathrm{~m}$ & $11 \mathrm{~m}$ & $1 \mathrm{~m}$ & $0,3 \mathrm{~m}$ & $0,6 \mathrm{~m}$ & Tangerang Selatan (BL2) \\
\hline 4 & $22 \mathrm{~m}$ & $21 \mathrm{~m}$ & $1 \mathrm{~m}$ & $0,3 \mathrm{~m}$ & $0,6 \mathrm{~m}$ & Sumatra Utara (BL1) \\
\hline 5 & $24 \mathrm{~m}$ & $23 \mathrm{~m}$ & $1 \mathrm{~m}$ & $0,3 \mathrm{~m}$ & $0,6 \mathrm{~m}$ & Tangerang Selatan (BL1) \\
\hline 6 & $26 \mathrm{~m}$ & $25 \mathrm{~m}$ & $1 \mathrm{~m}$ & $0,3 \mathrm{~m}$ & $0,6 \mathrm{~m}$ & Tangerang Selatan (BL3) \\
\hline 7 & $29 \mathrm{~m}$ & $28 \mathrm{~m}$ & $1 \mathrm{~m}$ & $0,3 \mathrm{~m}$ & $0,6 \mathrm{~m}$ & Jakarta Pusat (BL2) \\
\hline
\end{tabular}

Tabel 3. Hasil perhitungan dari spreadsheet dan software komputer

\begin{tabular}{|c|c|c|c|c|c|c|c|c|}
\hline \multirow{2}{*}{$\begin{array}{l}\text { Tiang } \\
\text { No. }\end{array}$} & \multicolumn{4}{|c|}{ Spreadsheet } & \multicolumn{4}{|c|}{ Software Komputer } \\
\hline & $\mathrm{Q}_{\mathrm{s}}$ & $\mathrm{Q}_{\mathrm{p}}$ & Qult & $\mathrm{S}_{\text {total }}$ & $\mathrm{Q}_{\mathrm{s}}$ & $\mathrm{Q}_{\mathrm{p}}$ & Qult & $\mathrm{S}_{\text {total }}$ \\
\hline 1 & $165.9 \mathrm{kN}$ & $437.91 \mathrm{kN}$ & $603.81 \mathrm{kN}$ & $2.2 \mathrm{~cm}$ & $159.548 \mathrm{kN}$ & $479.668 \mathrm{kN}$ & $639.216 \mathrm{kN}$ & $1.6 \mathrm{~cm}$ \\
\hline 2 & $299.11 \mathrm{kN}$ & $757.3 \mathrm{kN}$ & $1056.41 \mathrm{kN}$ & $6.6 \mathrm{~cm}$ & $241.328 \mathrm{kN}$ & $812.878 \mathrm{kN}$ & $1054.206 \mathrm{kN}$ & $5.5 \mathrm{~cm}$ \\
\hline 3 & $515.15 \mathrm{kN}$ & $757.3 \mathrm{kN}$ & $1272.44 \mathrm{kN}$ & $6.7 \mathrm{~cm}$ & $650.353 \mathrm{kN}$ & $812.875 \mathrm{kN}$ & $1463.228 \mathrm{kN}$ & $5.1 \mathrm{~cm}$ \\
\hline 4 & $622.94 \mathrm{kN}$ & $757.3 \mathrm{kN}$ & $1380.24 \mathrm{kN}$ & $7 \mathrm{~cm}$ & $331.44 \mathrm{kN}$ & $812.878 \mathrm{kN}$ & $1144.318 \mathrm{kN}$ & $6.3 \mathrm{~cm}$ \\
\hline 5 & $1286.61 \mathrm{kN}$ & $757.3 \mathrm{kN}$ & $2043.91 \mathrm{kN}$ & $7.6 \mathrm{~cm}$ & $1034.664 \mathrm{kN}$ & $812.878 \mathrm{kN}$ & $1847.542 \mathrm{kN}$ & $9 \mathrm{~cm}$ \\
\hline 6 & $1229.5 \mathrm{kN}$ & $387.83 \mathrm{kN}$ & $1617.33 \mathrm{kN}$ & $6 \mathrm{~cm}$ & $1061.541 \mathrm{kN}$ & $481.195 \mathrm{kN}$ & $1542.736 \mathrm{kN}$ & $2.8 \mathrm{~cm}$ \\
\hline 7 & $635.64 \mathrm{kN}$ & $234.26 \mathrm{kN}$ & $869.9 \mathrm{kN}$ & $2.7 \mathrm{~cm}$ & $420.913 \mathrm{kN}$ & $285.765 \mathrm{kN}$ & $706.678 \mathrm{kN}$ & $2.1 \mathrm{~cm}$ \\
\hline
\end{tabular}

Tabel 4. Besar selisih perhitungan dari spreadsheet dan software komputer

\begin{tabular}{cccccc}
\hline $\begin{array}{c}\text { Tiang } \\
\text { No. }\end{array}$ & $\begin{array}{c}\text { Panjang } \\
\text { Tiang }\end{array}$ & $\begin{array}{c}\text { Selisih } \\
\mathrm{Q}_{\mathrm{s}}\end{array}$ & $\begin{array}{c}\text { Selisih } \\
\mathrm{Q}_{\mathrm{p}}\end{array}$ & $\begin{array}{c}\text { Selisih } \\
\mathrm{Q}_{\mathrm{ult}}\end{array}$ & $\begin{array}{c}\text { Selisih } \\
\mathrm{S}_{\text {total }}\end{array}$ \\
\hline 1 & $6 \mathrm{~m}$ & $3.8 \%$ & $8.7 \%$ & $5.5 \%$ & $27.3 \%$ \\
\hline 2 & $10 \mathrm{~m}$ & $19.3 \%$ & $6.8 \%$ & $0.2 \%$ & $16.7 \%$ \\
\hline 3 & $12 \mathrm{~m}$ & $20.8 \%$ & $6.8 \%$ & $13 \%$ & $23.9 \%$ \\
\hline 4 & $22 \mathrm{~m}$ & $46.8 \%$ & $6.8 \%$ & $17.1 \%$ & $10 \%$ \\
\hline 5 & $24 \mathrm{~m}$ & $19.6 \%$ & $6.8 \%$ & $9.6 \%$ & $15.6 \%$ \\
\hline 6 & $26 \mathrm{~m}$ & $13.7 \%$ & $19.4 \%$ & $4.6 \%$ & $53.3 \%$ \\
\hline 7 & $29 \mathrm{~m}$ & $33.8 \%$ & $18 \%$ & $18.8 \%$ & $22.2 \%$ \\
\hline
\end{tabular}

Dari tabel 4, dibuat grafik agar dapat diketahui bagaimana trendline yang dihasilkan dari perbandingan yang dilakukan. Grafik tersebut dapat dilihat pada gambar 2, gambar 3, gambar 4 dan gambar 5. 

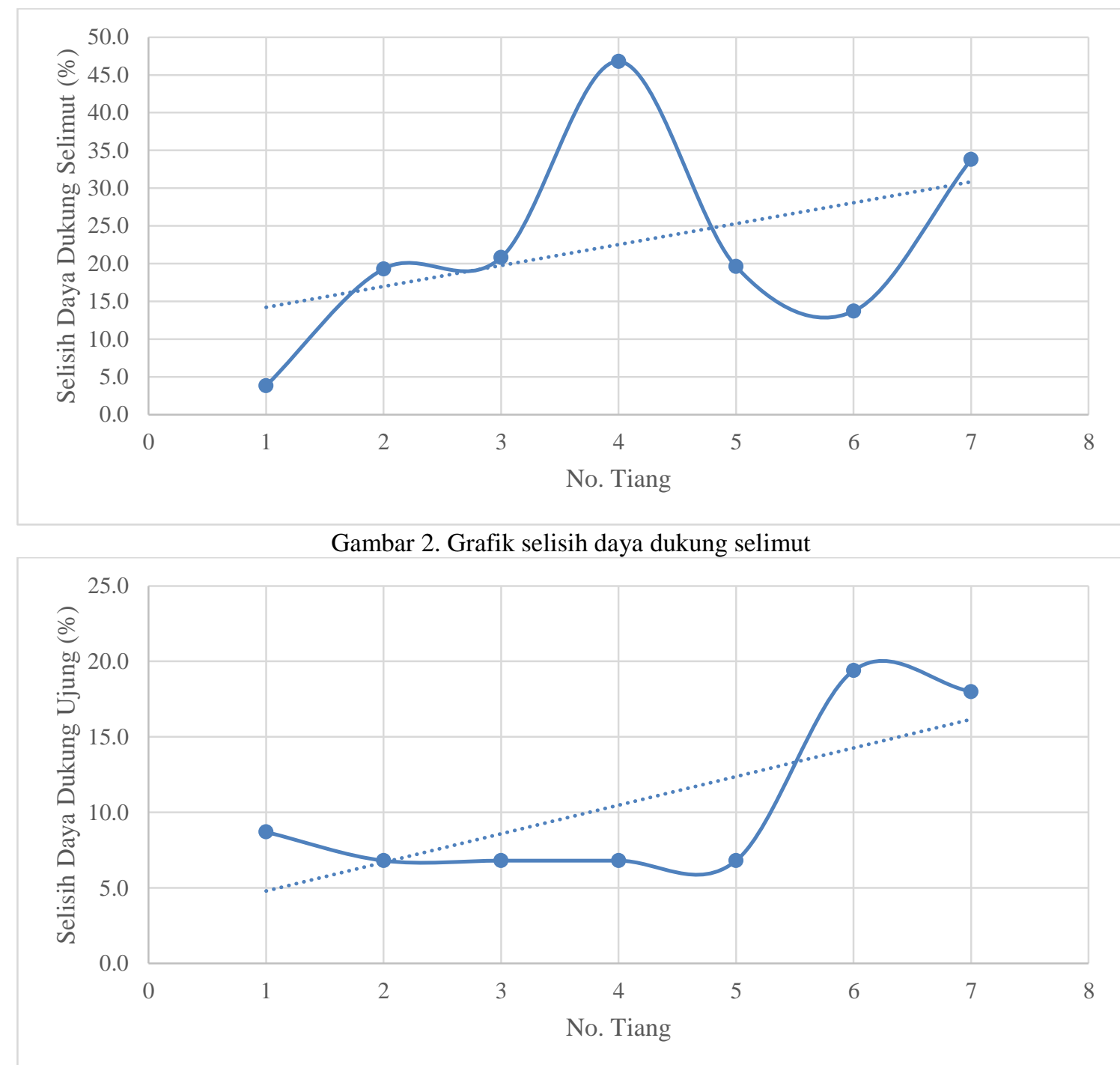

Gambar 3. Grafik selisih daya dukung ujung

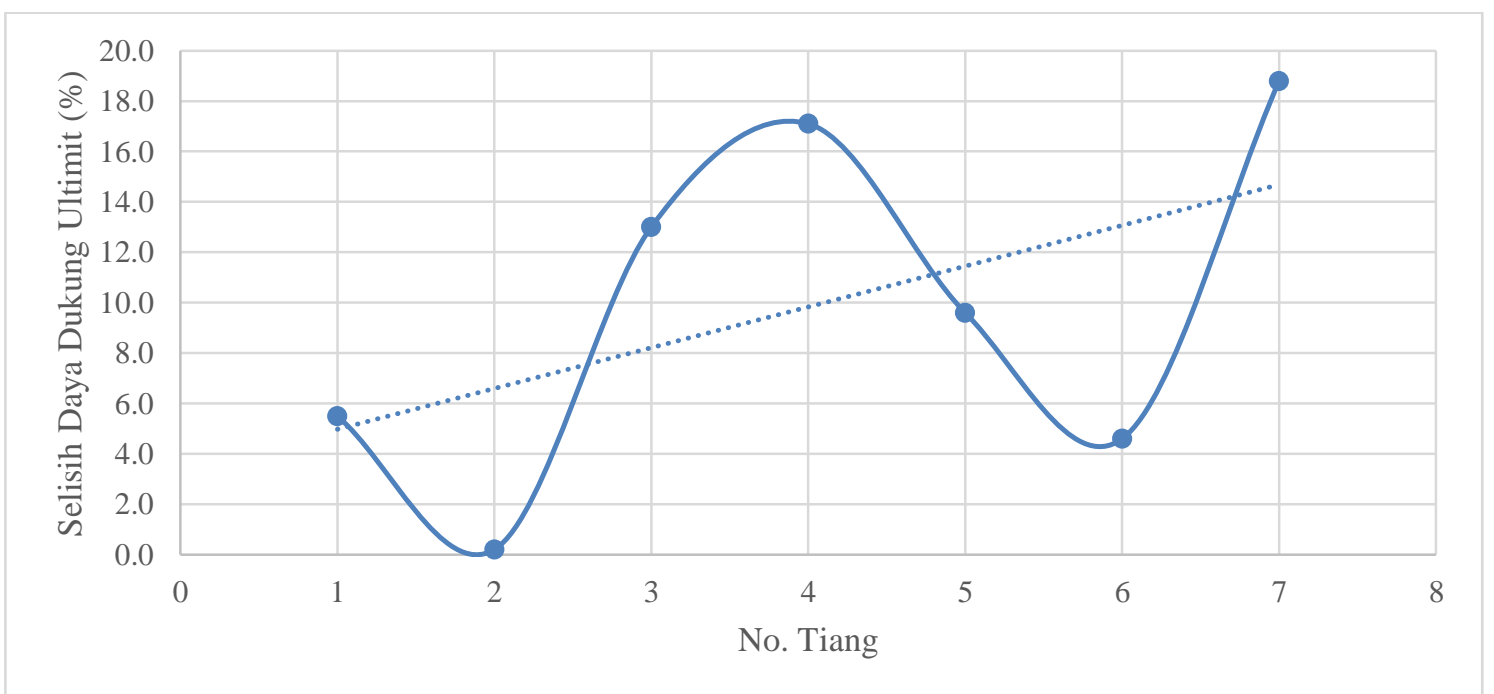

Gambar 4. Grafik selisih daya dukung ultimit 


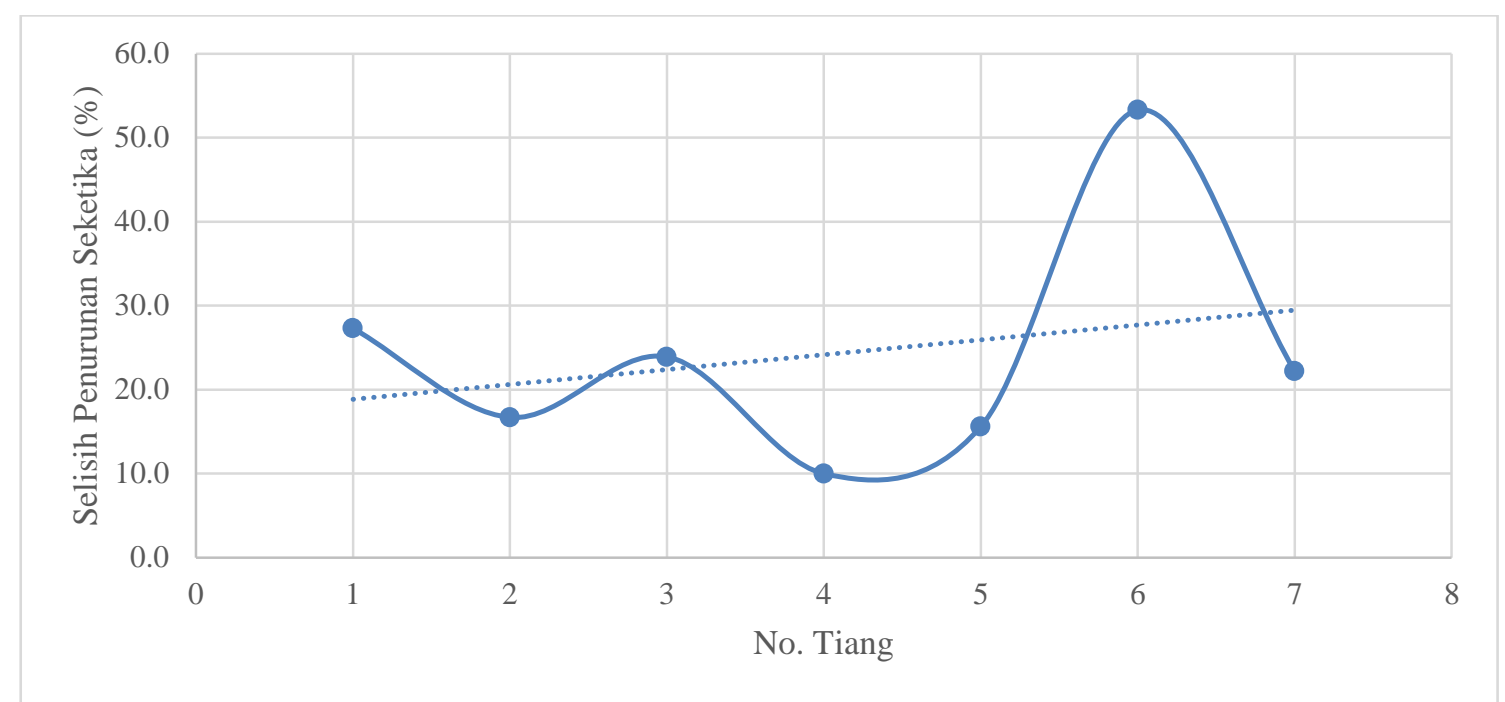

Gambar 5. Grafik selisih penurunan seketika

Pada gambar 2, grafik selisih daya dukung selimut antara perhitungan dari spreadsheet dengan software komputer antara $14 \%$ sampai $31 \%$. Sementara pada gambar 3, grafik selisih daya dukung ujung antara perhitungan dari spreadsheet dengan software komputer antara 5\% sampai $16 \%$. Dan pada gambar 4, grafik selisih daya dukung ultimit antara perhitungan dari spreadsheet dengan software komputer antara 5\% sampai $15 \%$. Terakhir pada gambar 5, menunjukkan grafik selisih penurunan seketika antara perhitungan dari spreadsheet dengan software komputer antara 19\% sampai $29 \%$. Salah satu faktor terbesar penyebab selisih antara perhitungan dari spreadsheet dengan software komputer adalah jenis tanah di ujung dan sekitar selimut fondasi enlarged base. Karena pada jenis tanah seperti lempung, lanau dan pasir bisa terjadi perbedaan hasil korelasi parameter tanah, dan juga dapat terjadi perbedaan cara menghitung daya dukung dan penurunan fondasi enlarged base. Oleh sebab itu, pada tabel 5 dapat dilihat bagaimana kondisi tanah pada sekitar selimut dan ujung fondasi enlarged base yang digunakan sebagai contoh.

Tabel 5. Keterangan kondisi tanah pada contoh fondasi enlarged base

\begin{tabular}{ccc}
\hline $\begin{array}{c}\text { Tiang } \\
\text { No. }\end{array}$ & $\begin{array}{c}\text { Jenis Tanah Sekitar } \\
\text { Selimut Tiang }\end{array}$ & Jenis Tanah pada Ujung Tiang \\
\hline 1 & Lempung lunak-keras & Lempung keras \\
\hline 2 & Pasir keras & Lempung lunak \\
\hline 3 & Pasir keras & Lanau lunak \\
\hline 4 & Pasir keras & Lanau sedang-keras \\
\hline 5 & Pasir keras & Lanau sedang-keras \\
\hline 6 & Lanau keras & Lempung dan lanau sedang-keras \\
\hline 7 & Lempung sedang & Lanau lunak \\
\hline
\end{tabular}

\section{KESIMPULAN}

Dari analisis perbandingan perhitungan fondasi enlarged base pada spreadsheet dengan software komputer pada point 5, diperoleh kesimpulan bahwa untuk perhitungan daya dukung ujung fondasi nilai selisih berbeda tergantung dari jenis tanah pada ujung fondasi, pada tanah pasir diperoleh selisih hanya 6.8\% pada ke empat contoh fondasi (dapat dilihat pada tabel 4), sedangkan pada tanah lempung dan lanau besar selisih yang diperoleh antara $8 \%$ sampai $19 \%$.

Dan untuk perhitungan daya dukung selimut fondasi enlarged base, hasilnya cukup besar karena ada perbedaan asumsi bagian mana saja yang memberikan daya dukung selimut, akan tetapi faktor jenis tanah juga mempengaruhi besar perbedaan yang diperoleh. Selanjutnya diperoleh selisih daya dukung selimut untuk tanah pasir dan lempung berkisar 3\% sampai 20\% dan pada tanah lanau selisihnya lebih besar yaitu 19\% sampai $46 \%$. Pada tanah lanau selisihnya lebih besar juga dapat disebabkan asumsi pada korelasi tanah yang berbeda, yaitu pada lanau tidak di 
anggap 100\% tanah kohesif, jadi dianggap memiliki besar sudut geser dalam. Lalu untuk perhitungan daya dukung ultimit fondasi enlarged base, dari point 5 menunjukkan hasil yang lebih baik, yaitu berkisar 0\% sampai 18\%. Dan untuk penurunan seketika besar selisihnya antara $10 \%$ sampai $27 \%$, akan tetapi pada fondasi yang ujung tanahnya lanau memiliki besar selisih 53\%. Sehingga dari analisis perbedaan hasil perhitungan daya dukung dan penurunan seketika fondasi enlarged pada spreadsheet dan pada software komputer, dapat disimpulkan bahwa hasil perhitungan spreadsheet dapat diandalkan untuk menghitung daya dukung ultimit dan penurunan fondasi enlarged base.

\section{DAFTAR PUSTAKA}

Bowles, J.E. (1992). Analisis dan Desain Pondasi (Edisi Keempat Jilid 1). Erlangga, Jakarta.

Coduto, D. P., Kitch, W. A., dan Yeung, M. R. (2016). Foundation Design: Principles and Practices (Third Edition). Pearson, California.

Deep Foundation Research Institute. (2013). Manual Pondasi Tiang Edisi 4. Geotechnical Engineering Center, Bandung.

Das, B. M. (2011). Principles of Foundation Engineering (Seventh Edition). Cengage Learning, United States of America.

Moch., S. (2008). Buku Bahan Ajar Rekayasa Pondasi. Politeknik Negeri, Malang. 